\title{
Clinical Study on the Effectiveness of Pippali Khanda in the Management of Amlapitta
}

\author{
Research Article
}

\section{Richa Singh $^{1^{*}}$, Girish KJ², Yadu Narayan Mooss ${ }^{3}$}

1. PG Scholar, 2. Professor, 3. Postgraduate Scholar, Department of Kayachikitsa, Sri Dharmasthala Manjunatheshwara College of Ayurveda \& Hospital, Hassan-573201, Karnataka, India.

\begin{abstract}
Background: Amlapitta (Acid peptic disorder) is disease of the Annavaha Srotas (gastrointestinal tract) which results primarily because of indulgence in A hita A hara Vihara Sevana (irregular dietary habit and day to day activity). Khanda (sugar granules) is widely acceptable dosage forms in the present scenario due its palatability, shelf life and easy administration. The selected drug Pippali Khanda possesses Deepana (enhances digestion), Pachana (digestive) and Vatanulomana (regulates Vata). Study has been undertaken to evaluate the effectiveness of Pippali Khanda in the management of Urdhvaga Amlapitta having dominance of Kapha and Pitta Dosha. Methods: Among the 32 registered patients 30 of them completed the course of treatment. Pippali Khanda was administered in a dose of three gram twice daily, fifteen minutes after food, for fifteen days. Patients were assessed before, end of first of week and $15^{\text {th }}$ day of treatment. For statistical analysis, ordinal data were assessed by Friedman's test and Wilcoxon signed rank as Post Hoc after applying Bonferroni correction. Results: There were statistically highly significant improvements in the signs and symptoms of Amlapitta. $(\mathrm{p}<0.05)$ observed. Conclusion: Pippali Khanda is effective and useful in the management of signs and symptoms of Amlapitta besides improved the parameters of Agni and digestion.
\end{abstract}

Keywords: Ayurveda, acid peptic disorder, Am lapitta, Pippali Khanda, Agni.

\section{Introduction}

Amlapitta (acid peptic disorder) is one of the commonest Annavaha Srotas Vyadhi (gastrointestinal tract disorder) (1). When any of causative / triggering factors causes Mandagni (reduced digestive power), it leads to undigested food particles (Vidagdhajirna) manifesting as Amlapitta (2). Amlapitta is a condition where sour nature (Amla Guna) of Pachaka Pitta aggravates due to Shuktata of the undigested food (Anna) leading to burning sensation (Vidaha). Hence, Amlapitta being Pitta-Kapha Pradhana Tridoshaja Vyadhi, respective Lakshana of involved Dosha will be seen according to variation of involved Dosha.

In the management of Amlapitta, Vamana (emesis) or Virechana (purgation) are the main line of Shodhana (detoxification) and followed by this, Langhana (fasting), LaghuBhojana (light digestive food) and Agnideepana (enhances digestion) measures to adopt (3). A population-based study, using a validated questionnaire, found that $58.7 \%$ of the population has heartburn or acid regurgitation at least once during the course of a year and that $19.8 \%$

\section{*Corresponding Author:}

\section{Richa Singh,}

PG scholar, Department of Kayachikitsa,

Sri Dharmasthala Manjunatheshwara College of Ayurveda \& Hospital,

Hassan-573201, Karnataka, India.

Email address: $\underline{r . s i n g h .0388 @ g m a i l . c o m ~}$ experience symptoms at least once weekly. It is estimated that approximately $50 \%$ of patients with typical reflux symptoms have erosive oesophagitis. Pippali Khanda is Katu (pungent), Madhura (sweet), Tikta (bitter) in Rasa, Laghu (lightness) Ruksha (dry) in Guna, Veerya is Sheeta (cold), Vipaka is Madhura (sweet) and Doshagnatha is Pitta Kaphahara. Pippali is the best medicine for Amapachana and alleviates the Srotasrodha by Laghu Tikshna Guna. Hence drug was selected.

\section{Objectives}

The study was conducted to assess clinical effectiveness of Pippali Khanda in the management of Urdhvaga Amlapitta.

\section{Methodology}

Source of data:

Patients were recruited from outpatient and inpatient unit of Department of Kayachikitsa, Sri Dharmasthala Manjunatheshwara College of Ayurveda and Hospital, Hassan, Karnataka, India.

\section{Methods of collection of data:}

Patients were screened and selected based on the screening form. A case report form was prepared with all points of history taking, physical signs and symptoms of Urdhvaga Amlapitta. The selected patients were subjected to detail clinical history and complete physical examination before undergoing the clinical study. Institutional ethics clearness was obtained from 
Institutional Ethics Committee, Sri Dharmasthala Manjunatheshwara College of Ayurveda \& Hospital, Hassan (SDM/ICE/45/2014-2015 dated 01-04-2015) and study was registered in Clinical Trials Registry of India (CTRI/2016/05/006918).

\section{Diagnostic criteria:}

Diagnosis was made on the basis of Samanya Lakshanas of Urdhvaga Amlapitta viz. Hrullasa (nausea), Mandagni (reduced digestive power ), Chardi (vomiting), Kaphanishteevan (excessive salivation), Bhuktevigdagdha (burning sensation after food intake), Utklesha (sour belching), Tikta- Amla Udgahra (bittersour belching), Klama (triedness), Gaurava (heaviness), Hrith- Kanta daha (burning sensation of throat and chest region), Analasada (reduced food intake) and Aruchi (lack of taste) (4).

\section{Inclusion Criteria:}

Patients with chronicity upto 5 years between age group of 18-55 years of either gender, irrespective of socio-economic status and those who are ready to sign the informed consent form were included.

\section{Exclusion criteria:}

Patients with history of systemic illness namely diabetic mellitus and hypertension, thyroid disorders, cardiac pathology, immunodeficiency disorders like AIDS, Parinama Shula (gastric ulcer, duodenal ulcer), Annadrava Shula, Krimiroga (worms manifestation) and Arbuda(tumour), hematemesis, melena and anaemia, drug, alcohol and tobacco induced Amlapitta were excluded. Routine laboratory investigations were performed to rule out any major pathology.

\section{Intervention:}

The trial drug Pippali Khanda(5) is taken from Amlapitta Adhikaara of Bhaishajya Ratnavali for the management of Urdhvaga A mlapitta.

Table 1: list of ingredients, Latin names, part used and quantity of Pippali K handa

\begin{tabular}{|l|l|l|l|l|}
\hline Sl. & Sanskrit Name & Botanical name & Part used & Proportion \\
\hline 1 & Pippali & Piper longum & Dried rhizome & 15 parts \\
\hline 2 & Satavari & Asparagus racemosus & Decoction & 32 parts \\
\hline 3 & Amalaki & Emblica officinalis & Fruit & 1 part \\
\hline 4 & Dhanyaka & Coriander sativum & Fruit & 1 part \\
\hline 5 & Krishna jiraka & Carum bulbocastanum & Seed & 1 part \\
\hline 6 & Twak & Cinnamomum zeylanicum & Bark & 1 part \\
\hline 7 & Ela & Elettaria cardamomum & Seed & 1 part \\
\hline 8 & Tejapatra & Cinnamomum tamala & Leaf & 1 part \\
\hline 9 & Mustaka & Cyperus rotundus & Tuber & 1 part \\
\hline 10 & Swetajiraka & Cuminum cyminum & Seed & 1 part \\
\hline 11 & Shunti & Zingiber officinale & Dried rhizome & 1 part \\
\hline 12 & Vamsalochana & Bambusa arundinaceae & & 1 part \\
\hline 13 & Haritaki & Terminalia chebula & Fruit rind & 1 part \\
\hline 14 & Khadir & Acacia catechu & Sara & $1 / 2$ part \\
\hline 15 & Maricha & Piper nigrum & Fruit & 1 part \\
\hline 16 & Ghrita & & & 23 parts \\
\hline 17 & Goksheera (Cow milk) & & & 125 parts \\
\hline 18 & Madhu (Honey) & & & 12 parts \\
\hline 19 & Mishri (Sugar) & & 70 parts \\
\hline
\end{tabular}

\section{Method of Preparation of Pippali Khanda:}

Ksheera (milk) was boiled with Pippali churna (powder) on mriduagni. When paste was formed than, it was mixed with Go ghrita, Satavari kwatha (decoction) and sugar, fried on mridhuagni until Ghrita got separated from the paste form. When Paka Lakshanas were obtained, vessel taken out of the fire and Sukshma Churna (fine powder) of Prakshepaka drugs was added and mixed uniformly. After it gets cooled, Madhu (honey) was added to it. (6) 
Packing:

Prepared drug was packed in airtight bottle, properly labelled and weighted $100 \mathrm{gm}$.

\section{Dosage:}

3 gm twice daily

\section{Duration:}

15 days

\section{Anupana:}

Normal water and milk (7)

\section{Pathyapthya:}

For diet list of included items are as follow old rice, barley, wheat, mudga, cool boiled water, sugar, honey, well ripened fruit of white gourd (kusmanda), pomegranate (dadima), gooseberry (Amalaki) and all bitter juices should be used. Spicy food item should be avoided along with oily and fried items.

\section{Assessment Criteria}

The effect of therapy was assessed on the basis of changes in signs and symptoms of Urdhvaga A mlapitta using questionnaire that was developed for the study. Patients were assessed at three intervals i. e. before, end of first of week and $15^{\text {th }}$ day of treatment. These were assessed by giving specific scores which were helpful in Statistical analysis. These scores are presented as follows.

Do you have vomiting sensation (Hrullasa)

$$
\begin{aligned}
& 0 \text { - No } \\
& 1 \text { - Very less } \\
& 2 \text { - Sometime } \\
& 3 \text { - Always }
\end{aligned}
$$

Do you have appetite (Aruchi)

$$
\begin{aligned}
& 0 \text { - No } \\
& 1 \text { - Very less } \\
& 2 \text { - Sometime } \\
& 3 \text { - Always }
\end{aligned}
$$

Do you have feeling of indigestion (Mandagani)

$$
\begin{aligned}
& 0 \text { - No } \\
& 1 \text { - Very less } \\
& 2 \text { - Sometime } \\
& 3 \text { - Always }
\end{aligned}
$$

Do you have Vomiting before and after food intake (Chardi)

$$
\begin{aligned}
& 0 \text { - No } \\
& 1 \text { - Very less } \\
& 2 \text { - Sometime } \\
& 3 \text { - Always }
\end{aligned}
$$

Increased frequency of sputum (Kapha nishteevan )

$$
\begin{aligned}
& 0 \text { - No } \\
& 1 \text { - Very less } \\
& 2 \text { - Sometime } \\
& 3 \text { - Always }
\end{aligned}
$$

Increased frequency of sour belching (Tiktamlodgara)

$$
0-\text { No }
$$

1 - Very less

2 - Sometime

3 - Always

Burning sensation of chest, throat and stomach region after taking food (Bhukte vidagdha)

$$
\begin{aligned}
& 0 \text { - No } \\
& 1 \text { - Very less } \\
& 2 \text { - Sometime } \\
& 3 \text { - Always }
\end{aligned}
$$

Burning sensation of chest, throat and stomach region (Hrith- kanta daha)

$$
\begin{aligned}
& 0 \text { - No } \\
& 1 \text { - Very less } \\
& 2 \text { - Sometime } \\
& 3 \text { - Always }
\end{aligned}
$$

Weakness effecting day to day activity (Analasada)

$$
\begin{aligned}
& 0 \text { - No } \\
& 1 \text { - Very less } \\
& 2 \text { - Sometime } \\
& 3 \text { - Always }
\end{aligned}
$$

Do you have abdominal pain (Udara shoola)

$$
\begin{aligned}
& 0 \text { - No } \\
& 1 \text { - Very less } \\
& 2 \text { - Sometime } \\
& 3 \text { - Always }
\end{aligned}
$$

Bitter taste of mouth. (Tiktasyata)

$$
\begin{aligned}
& 0 \text { - No } \\
& 1 \text { - Very less } \\
& 2 \text { - Sometime } \\
& 3 \text { - Always }
\end{aligned}
$$

Tongue coating present (Jihwalipta)

$$
\begin{aligned}
& 0 \text { - No } \\
& 1 \text { - Very less } \\
& 2 \text { - Sometime } \\
& 3 \text { - Always }
\end{aligned}
$$

Do you have headache (Shirashoola)

$$
\begin{aligned}
& 0 \text { - No } \\
& 1 \text { - Very less } \\
& 2 \text { - Sometime } \\
& 3 \text { - Always }
\end{aligned}
$$

Do you have heaviness of body (Shareera Gaurava)

$$
\begin{aligned}
& 0 \text { - No } \\
& 1 \text { - Very less } \\
& 2 \text { - Sometime } \\
& 3 \text { - Always }
\end{aligned}
$$

Do you have feeling of tiredness present (Klama)

$$
\begin{aligned}
& 0 \text { - No } \\
& 1 \text { - Very less } \\
& 2 \text { - Sometime } \\
& 3 \text { - Always }
\end{aligned}
$$

\section{Observation}

In this study among 32 patients 30 completed the whole treatment course, as 2 patients left the treatment due to their personal problems. 
Table 2: Demographic Profile of patients

\begin{tabular}{|c|c|c|c|}
\hline Geographic observation & Predominance & Precentage & No of patients \\
\hline Age (range 18-55yrs) & $28-37$ years & $53.1 \%$ & 17 \\
\hline Gender & Equally distributed(male and female) & $50.0 \%$ & 16 \\
\hline Marital status & Married & $87.5 \%$ & 28 \\
\hline Socio-economic status & Upper middle class & $62.5 \%$ & 20 \\
\hline Education status & Graduate & $46.9 \%$ & 15 \\
\hline Chronicity & More than 3 months & $50.0 \%$ & 16 \\
\hline Occupation & Profession & $40.6 \%$ & 13 \\
\hline Nature of work & Standing & $65.6 \%$ & 21 \\
\hline Working environment & Equally distributed & $50.0 \%$ & 16 \\
\hline Diet & Mixed & $87.5 \%$ & 28 \\
\hline Dietary Habits & Vishamashana & $65.6 \%$ & 21 \\
\hline Agni & Manda & $62.5 \%$ & 20 \\
\hline Koshtha & Madhyama & $78.1 \%$ & 25 \\
\hline
\end{tabular}

\section{Results}

Friedman's test $(\mathrm{p}<0.05)$ was applied to assess the significant change in the symptoms having ordinal data followed by Post hoc analysis with Wilcoxon signed rank tests was conducted with a Bonferroni correction applied, resulting in a significant level of $\mathrm{P}<0.017$ to interpret the time of significant change. (Table 3 )

Table 3: Parameters of Urdhvaga Amlapitta

\begin{tabular}{|c|c|c|c|c|}
\hline Serial No. & Parameter & Chi-Square & P value & Remark \\
\hline 1. & Hrullasa & 33.364 & 0.001 & Significant \\
\hline 2. & Mandagni & 32.000 & 0.001 & Significant \\
\hline 3. & Aruchi & 19.538 & 0.001 & Significant \\
\hline 4. & Chardi & 25.087 & 0.001 & Significant \\
\hline 5 & Kapha nishteevan & 13.556 & 0.001 & Significant \\
\hline 6 & Tiktamlodgara & 47.516 & 0.001 & Significant \\
\hline 7 & Bhukte vidagdha & 24.000 & 0.001 & Significant \\
\hline 8 & Utklesha & 12.250 & 0.001 & Significant \\
\hline 9 & Hrith-Kanta Daha & 48.000 & 0.001 & Significant \\
\hline 10 & Analasada & 21.143 & 0.001 & Significant \\
\hline 11 & Udara Shoola & 30.525 & 0.001 & Significant \\
\hline 12 & Tiktasyata & 18.667 & 0.001 & Significant \\
\hline 13 & Jihwalipta & 37.324 & 0.001 & Significant \\
\hline 14 & Shira shoola & 34.522 & 0.001 & Significant \\
\hline 15 & Shareera Gaurava & 35.521 & 0.001 & Significant \\
\hline 16 & Klama & 43.000 & 0.001 & Significant \\
\hline
\end{tabular}

\section{Discussion}

'Amlapitta' is a combination of two words A mla and Pitta. Among these two words the Amla denoted the Rasa (sour taste) and the Pitta denotes the Dosha involved in this disease. The Pitta Dosha is bestowed with the function of digestion and metabolism.

The overview of the ingredients of the drug suggests that dominant Rasa of the Combination in whole turns out to be Katu-Madhura Rasa followed by Tikta-Kashaya Rasa. All these three Rasas are Kapha-Pitta Hara in nature. Mainly Katu-Tikta Rasa is Kapha Hara, Tikta-Madhura is Pitta Dosha Hara, Where asKashaya is acting on both Kapha and Pitta. By this we can conclude that Pippali Khanda has the action of Agni Deepana, AmaPachana, Vatanulomana, Dahaprashamana (reduce burning sensation)and Trishnanigrahana (reduced thrist). 
Majority of parameters found statistically significant improvement at the level of $\mathrm{P}<0$. 001 (by Friedman test and post hoc Wilcoxson test analysis). All symptoms recorded at 3 intervals $i$. e. baseline, on $7^{\text {th }}$ day and on $15^{\text {th }}$ day.

\section{Effect of Pippali Khanda on parameter}

Table 4: Effect of Pippali Khanda on Parameters of Urdhvaga Amlapitta

\begin{tabular}{|c|c|c|}
\hline \multirow{2}{*}{ Parameter } & Reduction on $7^{\text {th }}$ day & Reduction on 15 $^{\text {th }}$ day \\
\cline { 2 - 3 } & No of patients (\%) & No of patients (\%) \\
\hline Hrullasa & $15(60.0 \%)$ & $11(44.0 \%)$ \\
\hline Mandagni & $12(50.0 \%)$ & $12(50.0 \%)$ \\
\hline Aruchi & $8(53.3 \%)$ & $9(60.0 \%)$ \\
\hline Chardi & $4(22.2 \%)$ & $12(66.6 \%)$ \\
\hline Kapha nishteevan & $4(36.3 \%)$ & $5(45.5 \%)$ \\
\hline Tiktamlodgara & $19(61.2 \%)$ & $20(64.5 \%)$ \\
\hline Bhukte vidagdha & $10(62.5 \%)$ & $10(62.5 \%)$ \\
\hline Utklesha & $3(30.0 \%)$ & $5(50.0 \%)$ \\
\hline Hrith-Kanta Daha & $19(59.3 \%)$ & $19(59.3 \%)$ \\
\hline Analasada & $10(71.4 \%)$ & $8(57.1 \%)$ \\
\hline Udara Shoola & $11(50.0 \%)$ & $12(54.5 \%)$ \\
\hline Tiktasyata & $4(30.7 \%)$ & $8(61.5 \%)$ \\
\hline Jihwalipta & $11(42.3 \%)$ & $15(57.6 \%)$ \\
\hline Shira shoola & $14(60.8 \%)$ & $13(56.5 \%)$ \\
\hline Shareera Gaurava & $15(57.6 \%)$ & $14(53.8 \%)$ \\
\hline Klama & $18(64.2 \%)$ & $18(64.2 \%)$ \\
\hline
\end{tabular}

On analysis from baseline and $15^{\text {th }}$ day effect, Pippali Khanda significantly reduced Hrullasa in 68. $7 \%$ patients, the sensation nausea caused due to the indigested food, Vruddha Kapha and Pitta. Second most important symptom, Mandagni caused due to both irregular dietary habit and improper Gati of Vata, Pippali Khanda effectly reduced Mandagni in 65. 6\% patients.

Chardi is primarily a gastro-intestinal symptom caused due to the stomach trying to empty its undigested or stale food material (Aama) and Vata moving in Pratiloma Gati, being Deepana, Pachana and Ama hara nature of drug contributes in reducing Chardi in 59. 3\% of sufferer.

Ama formation at Agni level cause Aruchi and Jihwalipta simultaneously which is neatly controlled by Tikta-Kashaya Rasa of Pippali khanda and reduced symptom in $81.2 \%$ of effected persons.

Shuktata of the Anna Rasa in time period will attained Shuktata vitiates the Pitta and causes Vidagdhata and Aruchi is maintained with Tridoshahara action of combination, reduces in $88.7 \%$ of patients. Pitta Dosha when vitiated has Amla Rasa dominant cause for Utklesha, Tiktamlodagara, Tiktasyata, Hrith -Kanta Daha and Analasada, all symptoms showed remarkable improvement.

On evaluating Sarvadahika symptoms, Dushti of SamanaVata, Pachaka Pitta and Kledaka Kapha along with the formation of Ama will give rise to Udaras hoola, same Dosha in later stage manifest into Shira shoola, Shareera Gaurava and Klama. So drug acting at Ama level having Deepana, Pachana property helps to reduces symptoms. PippaliKhanda has the action of Agni Deepana, A maPachana, Vatanulomana, Dahaprashamana and Trishnanigrahana helps in reducing above symptoms.

\section{Conclusion}

Pippali Khanda at a dose of 3gm twice daily, 15 minutes after food, orally for 15 days significantly reduced symptoms of Urdhvaga Amlapitta like Hrullasa, Mandagni, Chardi, Kaphanishteevan, , Utklesha, Hrit-kantaDaha, Analasada, Urdarashoola, Tiktasyata and Aruchi. The therapy also significantly improved Sarvadaihika Lakshana namely, Klama, Gaurava and Shirashoola. The trial drug dose not manifests any side effects, adverse reaction or untoward events in the patients of Urdhvaga A mlapitta.

\section{Acknowldgement}

The Authors thank Dr. Prasanna Narasimha Rao, Director, Principal, Sri Dharmasthala Manjunatheshwara College of Ayurveda, Hassan, Karnataka, India for providing the facilities for their guidance. The authors also like to thank the department of Department of Kayachikitsa,

SDM college of Ayurveda and Hospital, Hassan, Karnataka, India.

\section{References}

1. Sri Satyapala, Kashyapa Samhita with Vidyotinihindini Commentry, Varanasi: Choukambha Sanskrit Sansthan; 2010. p. 335. 
2. Sri Satyapala, Kashyapa Samhita, with Vidyotinihindi Commentry, Varanasi: Choukambha Sanskrit Sansthan;2010. p. 336.

3. Sri Satyapala, Kashyapa Samhita, with Vidyotini hindi Commentry, Varanasi: Choukambha Sanskrit Sansthan;2010. p. 337.

4. Madhavakara, Vijayarakshita, Srikantadatta, Tripathy B. Madhava Nidana with Madhukoshavyakhya and Vimala Madhudhara Hindi
Vyakhya. $2^{\text {nd }}$ edition. Varanasi: Chaukhamba Surabharati Prakashana. 2003; p. 228.

5. Mishra Siddhi Nandan. Bhaisajya Ratnavali with Siddhiprada Hindi commentary of Sen Das Govind. $1^{\text {st }}$ ed. Varanasi Chaukhambaorientalia; 2013. p 911

6. Mishra Siddhi Nandan. Bhaisajya Ratnavali with Siddhiprada Hindi commentary of Sen Das Govind. $1^{\text {st }}$ ed. Varanasi Chaukhamba Orientalia; 2013. p 911

7. Mishra Siddhi Nandan. BhaisajyaRatnavali with Siddhiprada Hindi commentary of Sen Das Govind. $1^{\text {st }}$ ed. Varanasi Chaukhamba Orientalia; 2013. 911. 